\section{The Quaternary fault in Jiamu area, the Xinjiang Uygur Autonomous Region}

\author{
LU Huafu ${ }^{1}$, WANG Shengli ${ }^{1}$, J. Suppe ${ }^{2}$, \\ A. Hubert-Ferarri ${ }^{2}$, JIA Dong, ${ }^{1}$, YAN Fuli ${ }^{1}$, \\ YIN Donghao ${ }^{1} \&$ CHEN Jian
}

1. Department of Earth Sciences, Nanjing University, Nanjing 210093, China;

2. Department of Geosciences, Princeton University, Princeton, New Jersey 08544 , USA

Correspondence should be addressed to Lu Huafu (e-mail: hflu@nju.edu. cn)

\begin{abstract}
The Quaternary Tailan River fault has been found in the Tianshan foothills area, the Xinjiang Uygur Autonomous Region. It is the recent boundary fault of the Tarim Basin coupling with the West Tianshan Mountains. In the light of measurement data of the slip which cuts the Quaternary deposits of different ages, the Quaternary kinematic figures of the Tailan River fault are estimated as follows: crustal shortening $3.7 \mathrm{~km}$ and shortening rate 1.59 $\mathrm{mm} / \mathrm{a}$, uplift of Tianshan Mountains $1.34 \mathrm{~km}$ and uplift rate $0.56 \mathrm{~mm} / \mathrm{a}$, and additional relief of $900 \mathrm{~m}$. Considering the contribution of the Gumubiezi anticline close to the south of the Tailan River fault, the Quaternary crustal shortening and shortening rate of the Jiamu area are $4.8 \mathrm{~km}$ and 2 $\mathrm{mm} / \mathrm{a}$ respectively. The above-mentioned data coincide with the crustal shortening rate calculated from the growth strata in the Kuqa area, as well as the GPS measurements in the Lake Issyk area and the Korla-Urumqi area, reflecting the fast thrusting period within the shortening tectonic processes of the rejuvenation foreland basin in front of the southern foothill of the West Tianshan Mountains since Neogene.
\end{abstract}

Keywords: coupling mechanics in the formation of basin and mountains of the Tarim basin-Tianshan Mountains, moraine, Quaternary fault, crustal shortening.

The Jiamu area, belonging to the Aksu City, the Xinjiang Uygur Autonomous Region, is located at the northern margin of the Tarim Basin, bordered by the southern foothill of the West Tianshan Mountains. It is part of the Wushi depression as the westward-extended part of the Kuqa Cenozoic rejuvenation foreland basin ${ }^{[1]}$. Peak Tumor and recent glaciers are located in the interior of the West Tianshan Mountains to the north of the research area. The Tailan River and the Taqlaq River originating from the glaciers flow southward through the southern foothill and the Jiamu area. The terraces develop along the rivers and the typical moraines distributed in the area play the roles of the indicators of the Quaternary structural deforma- tion. Huang ${ }^{[2]}$, Fedolovich et al. ${ }^{[3]}$, Shi Yafeng et al. ${ }^{[4]}$, Wang Jingtai ${ }^{[5]}$, and Liu Haichao et al. ${ }^{[6]}$ studied the characteristics and ages of the moraines from the 1940s to the 1990s, but there were no reports on the Quaternary fault and the relationship between it and the moraines. The present authors carried out the field exploration during the period of 1999-2000 and discovered the Tailan River fault which cuts through the Quaternary moraines and terraces ${ }^{1}$ The attitude of the fault plane was measured as the strike of $\mathrm{N} 70^{\circ} \mathrm{W}\left(290^{\circ}\right), 20^{\circ}$ dipping to north-northeast. Then the slip of the boundary fault between the South Tianshan Mountains and the Tarim Basin, the uplift caused by thrusting and crustal shortening rates were obtained.

\section{The Quaternary moraine and terraces}

The sediments in the Jiamu area are divided into early stage and late stage moraines and the terraces of four stages (figs. 1 and 2).

( i ) The moraine of the late stage. The moraine of the late stage $\left(\mathrm{M}_{\mathrm{VV}}\right)$ distributed at both banks of the Tailan River in the front of the Tianshan foothills exhibits two glacier sediments extending in N-S direction and having the shape of the outward convex in the map view, which were originally the southward terminal moraine arc deposited during the glaciation. After glaciation the arcuate front of terminal moraine was destroyed by the Tailan River and the moraine was divided into two pieces of eastern and western lateral convex moraine arcs. They are about $2 \mathrm{~km}$ long N-S trending, $300 \mathrm{~m}$ wide and $100 \mathrm{~m}$ high. Their slopes are about $20^{\circ}-30^{\circ}$. The sizes of the boulders in the moraine arcs are several meters to more than ten meters in diameter. The moraine debris on the surface keep their sharp edges, and the erosion and rounding to them are very weak. The late stage moraine $\left(\mathrm{M}_{\mathrm{IV}}\right)$ deposited upon the moraine of the early stage $\left(\mathrm{M}_{\mathrm{III}}\right)$. The above-mentioned features indicate that the moraine arcs are the product of the latest glaciation. According to the intact condition of the moraines, Federovich et al. ${ }^{[3]}$ and Shi Yafeng et al. ${ }^{[4]}$ named it the terminal moraine of the Pochenzhi glaciation, i.e. the products of the Wurm glaciation. The moraine age was inferred as the late stage of the late Pleistocene by Wang Jingtai ${ }^{[5]}$ and Shi Yafeng ${ }^{[3]}$. Liu Haichao ${ }^{[6]}$ compared the terminal moraine of the Pochenzhi glaciation with the moraine of the Upper Wangfeng Formation on the North Tianshan foothills, and the latter was dated as $(14.925 \pm 0.75) \times 10^{3}$ a by ${ }^{14} \mathrm{C}$ by Wang Jingtai ${ }^{[4]}$. The carbonate film in the moraine of the

1) Hubert-Ferrari, A., Suppe, J., Wang Xin et al., Active deformation in the Aksu area along the southern front of the Tianshan Mountains (China), in The Princeton 3D Structure Project Industrial Affiliates Program, Third Affiliates Meeting (ed. Suppe, J.), Princeton University, 2000. 


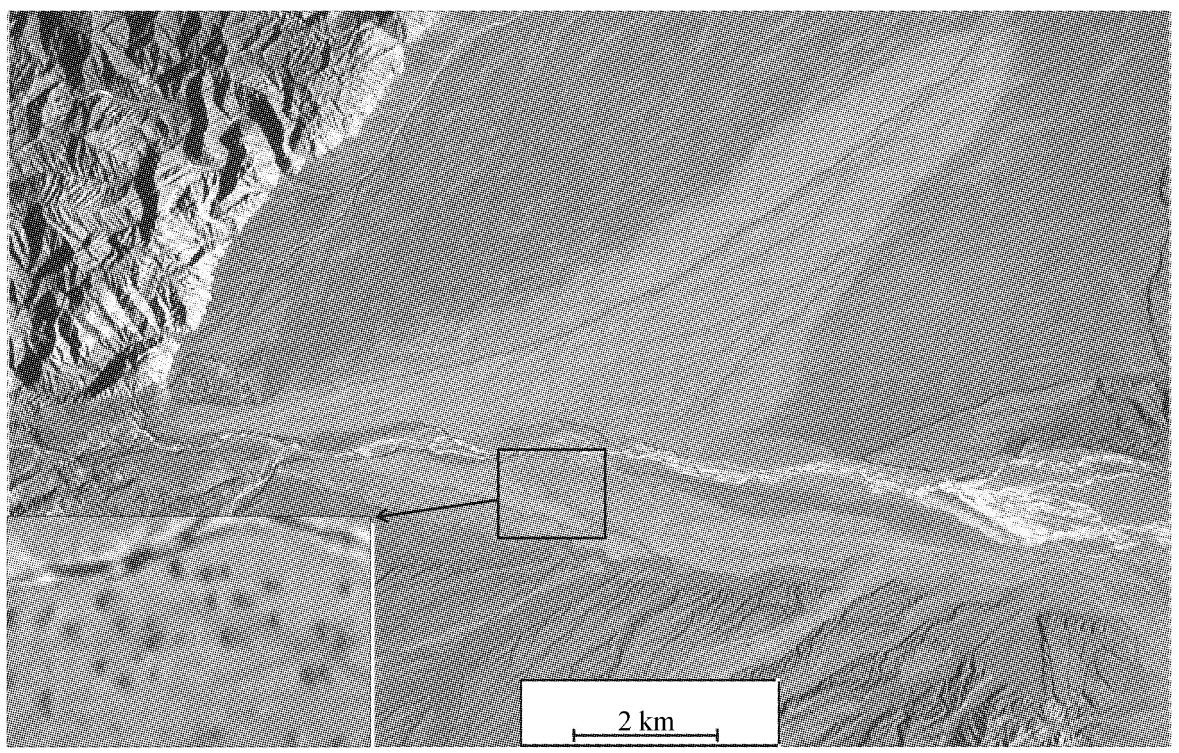

Fig. 1. Corona landsat photograph of the Jiamu area.

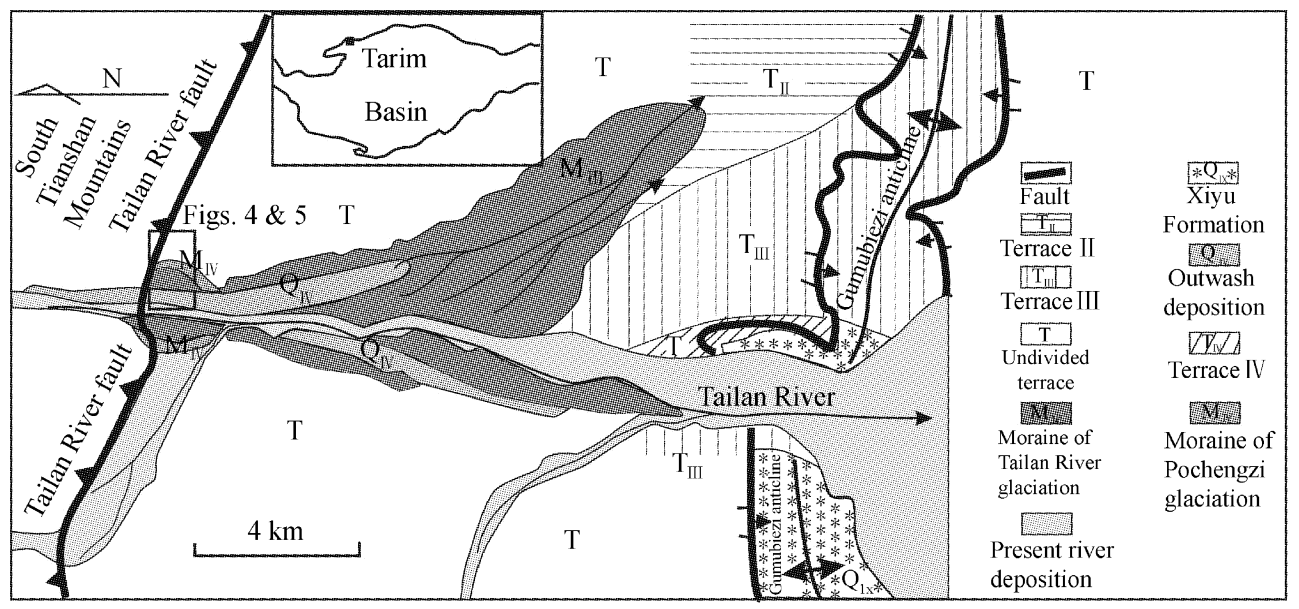

Fig. 2. The Quaternary geological map of the Jiamu area.

Upper Wangfeng Formation was dated as $(19-23) \times 10^{3}$ a by accelerating mass spectrometry (AMS) ${ }^{14} \mathrm{C}$ by $\mathrm{Yi}$ Chaolu et al. ${ }^{[7]}$. These geological features and dating data indicate that the latest stage moraine, i.e. the Pochengzi glaciation moraine, is the product of the Wurm glaciation. The outwash of the post-Wurm glaciation $\left(\mathrm{Q}_{\text {VV }}\right)$ deposited upon the early stage moraine $\left(\mathrm{M}_{\text {III }}\right)$. It exhibits the gravel bedding about $2-5 \mathrm{~m}$ thick on the top of $\mathrm{M}_{\mathrm{III}}$ at the north end of $\mathrm{M}_{\text {III }}$ (fig. 3). Some boulders of $\mathrm{M}_{\text {III }}$ protrude on the surface of the outwash (fig. 3). The loess covering the moraine of the Upper Wangfeng Formation was dated as
$(9.17 \pm 0.4) \times 10^{3}$ a by Guiyang Institute of Geochemistry ${ }^{[5]}$. The loess and the above-mentioned gravel of the outwash $\left(\mathrm{Q}_{\mathrm{V}}\right)$ are reasonable to be inferred as the contemporaneous post glaciation deposits. Therefore, the age of the outwash is estimated as $(9.17 \pm 0.4) \times 10^{3}$ a.

(ii) The moraine of early stage. The moraine of the early stage $\left(\mathrm{M}_{\mathrm{III}}\right)$ was named the Tailan River glaciation by Shi Yafeng ${ }^{[4]}$. It was studied by Huang ${ }^{[2]}$ in the area in the 1940s. The moraines appear like two lobes of tongues about $5 \mathrm{~km}$ wide and $10-15 \mathrm{~km}$ long trending southward from the Tailan River fault. Their outlines are 


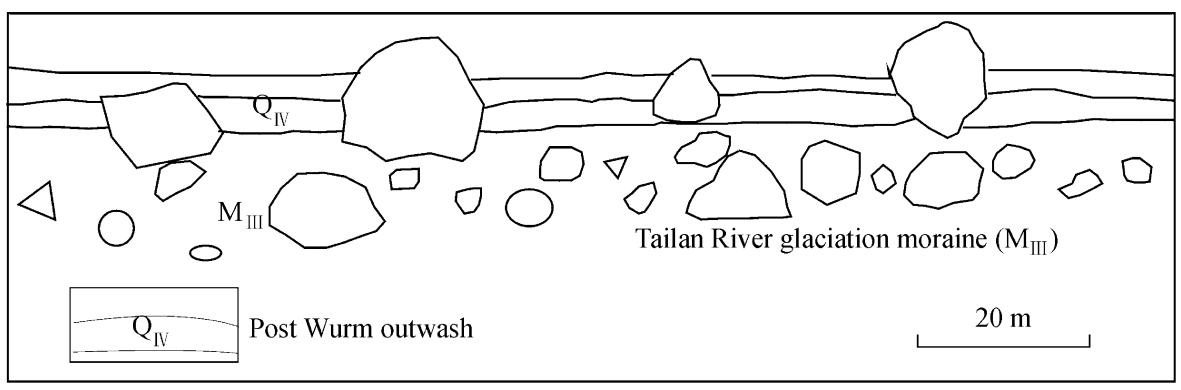

Fig. 3. Section of the post-Wurm glaciation outwash.

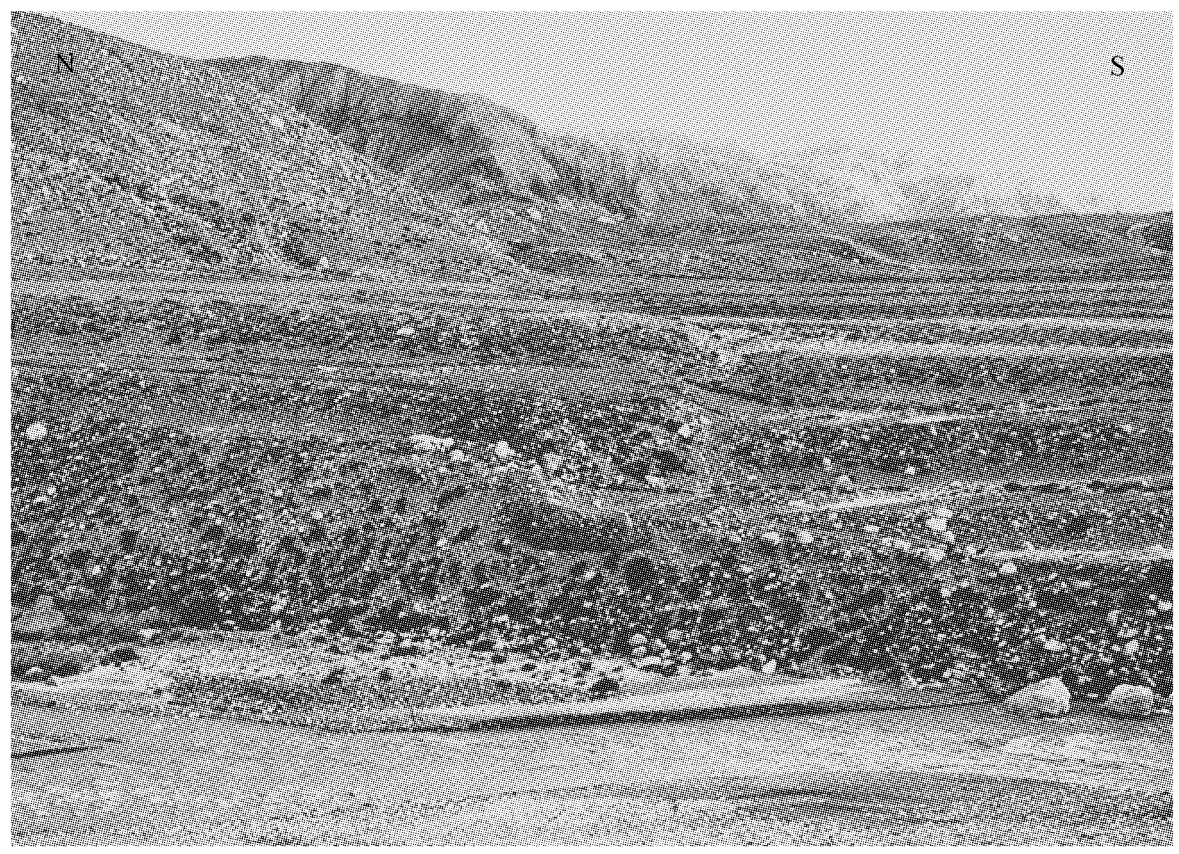

Fig. 4. Photo showing the Tailan River cutting through terraces $T_{I}, T_{I I}, T_{I I I}$, post-Wurm glaciation, outwash deposition $Q_{\mathbb{I V}}$, two glaciation moraines $\mathrm{M}_{\mathrm{III}}$ and $\mathrm{M}_{\mathrm{N}}$. Photo graphed toward east. For location see fig. 2.

quite clear in the landsat Corona photo (fig. 1). In the landsat photo there are innumerable spots in the moraine tongues (left corner insert in fig. 1). In fact the spots are huge boulders, which are $20-30 \mathrm{~m}$ in diameter. The boulders are various in petrology, including granites, schists, slates, granitoid gneisses, limestones, marbles, sandstones, basic igneous rocks and others, almost all kinds of rocks formed in the Paleozoic orogeny of the West Tianshan Mountains. In the northern parts of moraine tongues (about 1/4 length of them) the boulders are basically fresh being not deeply eroded. As settled southward the boulders are gradually eroded and their surface layers are collapsed. In the southern segments of the moraine tongues, the boulders are totally collapsed into small mounds, several to more than ten meters in height. The reason is that the melting glacial tongues retreated northward and dropped the boulders getting gradually younger northward, therefore the boulders are more deeply eroded southward.

In the northern part the debris on the surface of the moraine of the Tailan River glaciation are eroded deeper than those on the surface of the moraine of the Pochenzhi glaciation, with their edges rounded and surfaces polished, with the layer of desert varnish by aeolation on the debris surfaces. The moraine of the Pochenzhi glaciation $\left(\mathrm{M}_{\mathrm{VV}}\right)$ is deposited on the moraine of the Tailan River glaciation $\left(\mathrm{M}_{\text {III }}\right)$. The arcuate pattern of the moraines of the Pochenzhi glaciation superimposed the moraine tongues of the 
moraine of the Tailan River glaciation, confirming the time sequence of the moraines (figs. 1 and 2). Therefore, the moraine of the Tailan River glanciation must be older than the moraine of the Pochengzi glanciation and is regarded as the equivalence of the Riss glaciation in Europe. Shi Yafeng et al. ${ }^{[4]}$ inferred that it was deposited in the early stage of the late Pleistocene. Liu Haichao et al. ${ }^{[6]}$ contrasted it with the moraine of the Lower Wangfeng Formation located at the Urumqi River banks in the North Tianshan foothills. Wang Jingtai ${ }^{[5]}$ inferred, by the oxygen isotope cycle of Pacific ${ }^{[8]}$, that the age of the moraine of the Lower Wangfeng formation was $(140-170) \times 10^{3}$ a. Then the youngest limitation age of moraine of the Tailan River glaciation could be estimated to be $140 \times 10^{3}$ a. On the east bank of the Tailan River, at the western flank of the eastern lobe of the $\mathrm{M}_{\mathrm{III}}$ moraine tongue the moraine of the Tailan River glaciation is deposited on the top of the terrace $\mathrm{T}_{\mathrm{III}}$.

(iii) The terraces. In the research area there are four stages of terraces. The fourth terrace $\left(\mathrm{T}_{\mathrm{NV}}\right)$ of Pleistocene is not preserved much. The third terrace ( $\left.T_{\text {III }}\right)$ is the most wide spread high terrace. Generally it is $20-30 \mathrm{~m}$ higher than the river bed. It is composed of weakly cemented gravel and inferred to be the deposits of the middle Pleistocene. The second terrace $\left(\mathrm{T}_{\mathrm{II}}\right)$ and the first terrace $\left(T_{I}\right)$ are about $10 \mathrm{~m}$ and $5-7 \mathrm{~m}$ higher than the river bed respectively. Their sediments gravel gradually change southward into uncemented sand, silt and clay ones.

\section{The Tailan River fault}

The Tailan River fault located at the base of the southern foothill of the West Tianshan Mountains exhibits nearly E-W trending, dipping to the north. The hanging wall of the fault is the foothill of the Tianshan Mountains, belonging to the Tertiary sediments, and the footwall of the fault to the south is the Quaternary sediments of the north flank of the Tarim Basin. Topographically it plays the role of the boundary fault between the West Tianshan Mountains and the Tarim Basin (fig. 1). The Quaternary sediments on both banks of the Tailan River and Taqlak River exist at both walls of the fault, which provides good evidence of the geometry and kinematics for the fault.

Exposed on the right (west) bank cliff of the Tailan River the fault plane is $20^{\circ}$ dipping to the north. The fault cuts through terrances $T_{I}, T_{\text {II }}, T_{\text {III }}$, the outwash sediments of the post-Wurm glaciation $\left(\mathrm{Q}_{\mathrm{V}}\right)$, and the moraaines of the Pochengzi glaciation $\left(\mathrm{M}_{\mathrm{V}}\right)$ and the Tailan River glaciation $\left(\mathrm{M}_{\text {III }}\right.$. It can be seen on the left bank of the Taqlak River that the fault cuts through the post-Wurm outwash sediments $\left(\mathrm{Q}_{\mathrm{IV}}\right)$, forming a 7-m vertical slip through $(9.17$ $\pm 0.4) \times 10^{3}$ a. On the left (eastern) bank of the Tailan River, the fault cuts through terraces $\mathrm{T}_{\mathrm{I}}, \mathrm{T}_{\text {III }}, \mathrm{T}_{\text {III }}$, the
post-Wurm outwash sediments $\left(\mathrm{Q}_{\mathrm{IV}}\right)$ and the moraines of the Tailan River glaciation $\left(\mathrm{M}_{\mathrm{III}}\right)$ and the Pochengzi glaciation $\left(\mathrm{M}_{\mathrm{IV}}\right)$. The vertical slip of the moraine of the Tailan River glaciation $\left(\mathrm{M}_{\mathrm{III}}\right)$ cut by the thrusting of the fault is $80 \mathrm{~m}$ through $140 \times 10^{3} \mathrm{a}$. On the assumption of $140 \times 10^{3}$ a, the upper limit of the age of the Tailan River glaciation is the oldest limit of the average activity age of the Tailan River fault, the vertical slip velocity from $140 \times 10^{3}$ a to $(9.17 \pm 0.4) \times 10^{3}$ a can be calculated, i.e. the average relative velocity of mountain uplifting vs. basin depression is $V_{140-9}=(80 \mathrm{~m}-7 \mathrm{~m}) /\left(140 \times 10^{3} \mathrm{a}-9.17 \times 10^{3} \mathrm{a}\right)=0.56$ $\mathrm{mm} / \mathrm{a}$, which is based on the assumption that the fault emplaced as soon as the moraine of the Tailan River glaciation formed. But the fault might be emplaced at the time earlier than $140 \times 10^{3}$ a, therefore this vertical slip velocity is a minimum one. On the other hand, the fault could be active in the whole duration of Quaternary; then, if this velocity is extrapolated to the whole Quaternary, the uplift resulting from the fault could be estimated. Taking $2.4 \mathrm{Ma}$ as the duration of the Quaternary, the uplift of the West Tianshan Mountains is $S_{\mathrm{v}}=2.4 \mathrm{Ma} \times 0.56 \mathrm{~mm} / \mathrm{a}=$ $1.34 \mathrm{~km}$, which would not totally become the altitude of the topographical relief, because the sediments of several hundreds of meters were deposited on the footwall of the Tailan River fault, i.e. the basin depression and filling were developing during the period of the hanging wall uplift. So the visible real topographical relief caused by the thrusting of the Tailan River fault in Quaternary would be the magnitude calculated from the tectonic uplift, 1.34 $\mathrm{km}$ minus the thickness of the Quaternary sediments in the basin. The thickness expressed in the seismic profiles is about $500 \mathrm{~m}$, in different places of this region with some minor variance. It is also measured $450 \mathrm{~m}$ in the well A-1 located at $20 \mathrm{~km}$ east of the Wunxu County. This implicates that the mountain-basin boundary thrust or the Tailan River fault results in an additional relief of $900 \mathrm{~m}$ between the mountains and the basin during Quaternary.

Based on the $20^{\circ}$ of the dipping angle of the Tailan River thrust fault and the $1340 \mathrm{~m}$ of vertical slip, the horizontal fault slip $S_{\mathrm{h}}$ is calculated as $S_{\mathrm{h}}=S_{\mathrm{v}} / \operatorname{tg} 20^{\circ}=$ $3741 \mathrm{~m}$, i.e. the crustal shortening caused by the boundary thrust since the beginning of Quaternary. Then the shortening rate is $1.59 \mathrm{~mm} / \mathrm{a}$. According to the GPS measurement made by Abdrakhmatov et al ${ }^{[9]}$ in the Lake Issyk area of the West Tianshan Mountains in Kirghizstan, the crustal shortening rate of the single Quaternary fault is estimated as $1-2 \mathrm{~mm} / \mathrm{a}^{[9]}$, which coincides with our calculation.

\section{The Gumubiezhi anticline}

The Gumubiezhi anticline about $50 \mathrm{~km}$ long and 50 


\section{NOTES}

$\mathrm{m}$ high topographically, is located $20 \mathrm{~km}$ north of the Jiamu township, trending in the E-W direction. It consists of the early Pleistocene Xiyu gravel and terrace $\mathrm{T}_{\mathrm{IV}}$ on surface. For the subsurface, it is shown from the seismic profiles that, the Upper Gumubiezhi fault thrust southward during Pliocene and Quaternary ${ }^{1)}$. The hanging wall of the fault became a fault propagation anticline composed of Neogene and Quaternary sediments with a steep south limb. A back thrust on the Gumubiezi anticline developed near the surface and the Xiyu gravel and terrace $\mathrm{T}_{\text {IV }}$ sediments thrust backwards on themselves (fig. 6). The back thrust also cuts through terraces $\mathrm{T}_{\text {III }}$ and $\mathrm{T}_{\text {II }}$ (figs. 1 and 2). Undoubtedly it is a structure formed during Quaternary, and its deformation continued down to the deposition of the Xiyu gravel, terrace $\mathrm{T}_{\mathrm{IV}}, \mathrm{T}_{\mathrm{III}}$ and $\mathrm{T}_{\mathrm{II}}$, i.e. to the middle-late Pleistocene at least.

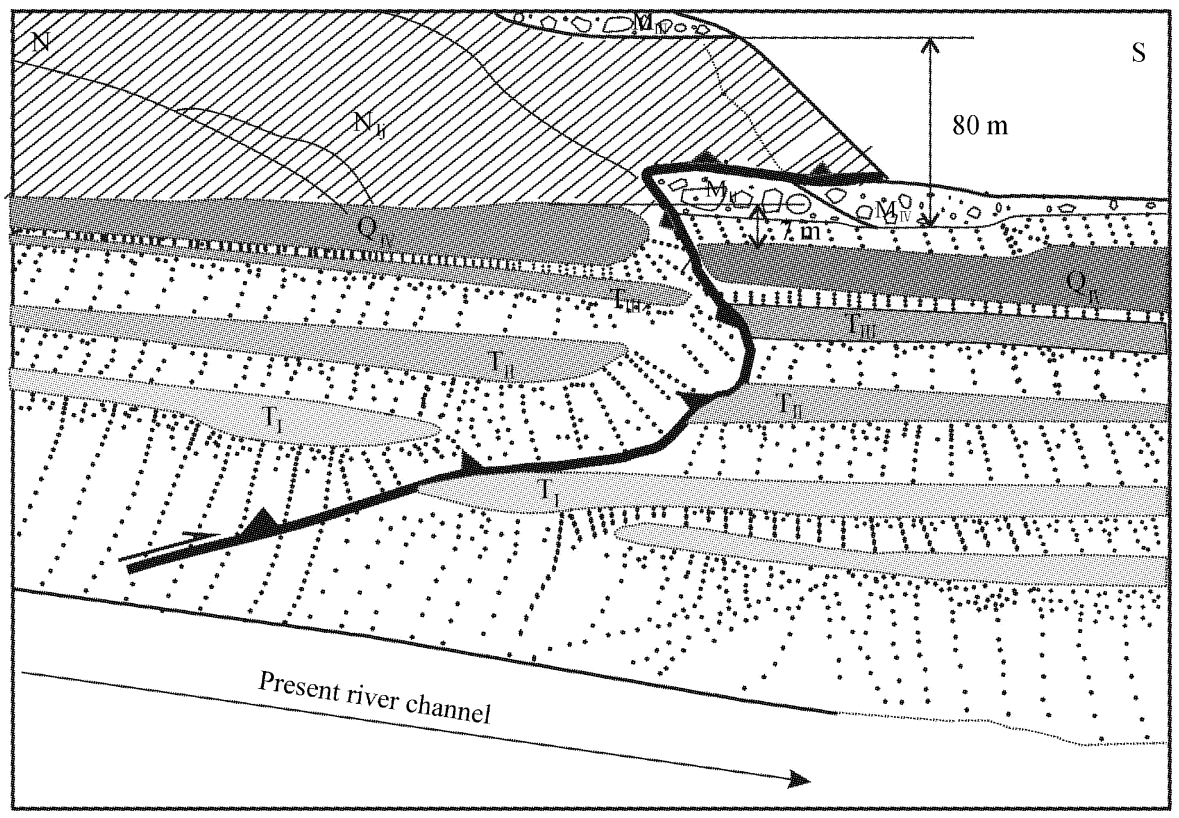

Fig. 5. Explanation of the photo in fig. 4.

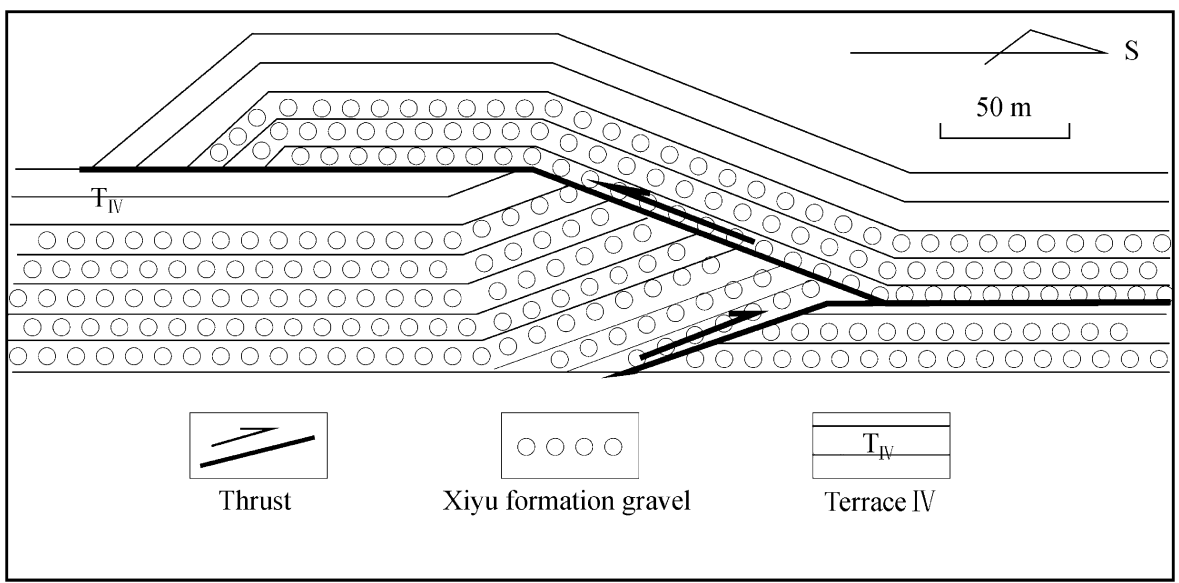

Fig. 6. Cross section of the Gumubiezi anticline through the eastern bank of the Tailan River. 2001

1) Lu Huafu, Xiao Ancheng, Jia Dong et al., Analysis and Evaluation of Structures of Keping Fault Uplift: a Research Report, Nanjing University, 


\section{Conclusion and discussion}

Being the main Quaternary foothill thrust in front of Peak Tomur in the West Tianshan Mountains, the Tailan River fault is a coupling boundary fault presently dividing the Tianshan Mountains and the recent Tarim Basin. It thrusts southward, forming the vertical slip of $1.34 \mathrm{~km}$, which is distributed into sediments of about $500 \mathrm{~m}$ in thickness in the basin and 900-m additional mountain-basin relief. The crustal shortening caused by the fault in Quaternary is $3.7 \mathrm{~km}$ and the shortening rate 1.59 $\mathrm{mm} / \mathrm{a}$, implicating that the shortening between the rejuvenation foreland basin and the mountains in the Kuqa area continued from the late Tertiary ${ }^{[10]}$ to Quaternary, thus providing reliable evidence for the coupling between the basin and the mountains with the thrust as the mechanics of kinematics. This is the latest expression of response of the interior Eurasia continent to the remote tectonic effects of the Indian/Tibetan continent-continent collision.

In the Jiamu area besides the Tailan River fault, the Upper Gummubiezi fault and its related anticline were formed in Pliocene and Pleistocene. The uplift of the anticline is not high, so we estimated that the additional amounts of the slip and deformation are very small. There is no other Quaternary structure in the area except the above-mentioned ones. Therefore, the Tailan River fault is the main Quaternary boundary fault of the Tarim Basin in the research area. According to the deformation of the Tailan River fault and the Gumubiezi anticline, the Quaternary crustal shortening rate in the Jiamu area is estimated at a bit more than $1.59 \mathrm{~mm} / \mathrm{a}$, maybe $2 \mathrm{~mm} / \mathrm{a}$. It exhibits the same magnitude as that in the Kuqa area, where the fast Pliocene-Quaternary crustal shortening rate, in the light of the study on the growth strata ${ }^{[10,11]}$, is estimated at 3-4 mm/a, and it approximates to the Quaternary crustal shortening rate $(3 \pm 1.5) \mathrm{mm} / \mathrm{a}$ calculated by Avouac $^{[12]}$ in the north Tianshan foothills. Based on the data of the repeated GPS measurements done by Ying Shaofen et al. ${ }^{[13]}$, $(7.20 \pm 0.87) \mathrm{mm}$ was shortened between Korla and Urumqi from 1994 to 1996, i.e. the shortening rate is $(3.60 \pm 0.43) \mathrm{mm} / \mathrm{a}$. Then, the contributation of the southern foothill thrust of the Tianshan Mountains to the shortening rate should be the half value of $(3.60 \pm 0.43) \mathrm{mm} / \mathrm{a}$, i.e. $(1.8 \pm 0.21) \mathrm{mm} / \mathrm{a}$. Korla is far away from the east to the research area and exhibits a reasonably lower shortening rate, because the crustal shortening was the strongest in the West Tianshan Mountains and very weak in the East Tianshan Mountains in Quaternary.

However, the Tailan River fault is not the northern boundary fault of the Kuqa rejuvenation foreland basin through the total duration of all Neogene and Quaternary, because there are large amounts of the Tertiary systems distributed to the north of the Tailan River fault. In the Tertiary system there exist many thrusts and fault-related folds formed during Tertiary, from which it can be seen that the northern boundary fault of the rejuvenation basin has not been fixed here since Miocene. Only in Quarternary did it migrate southward to the Tailan River fault. That is one of the important features of the mountain/ basin coupling boundary fault.

Acknowledgements We thank Jia Chenzhao and Tarim Oil Co. for their help in our field work. This work was supported by the National Natural Science Foundation of China (Grant No. 49832040.)

\section{References}

1. Lu, H., Howell, D. J., Jia, D. et al., Rejuvenation of the Kuqa foreland basin, northern flank of the Tarim Basin, Northwest China, International Geology Review, 1994, 36: 1151.

2. Huang, T. K., Chang, Y. C., Pleistocene morainic and non-morainic deposites in the Taqlaq area, North of Aqsu, Sinkiang, Bulletin of Geological Society of China, 1944, 24(1-2): 125.

3. Federovich, B. A., Yan Qinshang, Times and features of glaciation in Tianshan, China, Quaternary Research (in Chinese), 1960, 3(1 -2): 9 .

4. Shi Yafeng, Zheng Benxing, Su Zhen et al., Study of Quaternary glaciation in the Mts Tomor-Hantengri area, Tianshan, Journal of Glaciology and Cryopedology (in Chinese with English abstract), 1984, 2(6): 1 .

5. Wang Jingtai, Ancient glaciers at the head of Urumqi River, Tianshan, Journal of Glaciology and Cryopedology (in Chinese with English abstract), 1981, 3 (Supplement): 57.

6. Liu Haichao, Xie Zichu, Juregailov, M. B., Glaciation in Tianshan (in Chinese), Beijing: Science Press, 1998, 12-17.

7. Yi Chaolu, Liu Kexing, Cui Zhijiu, AMS dating on glacial tills at the sources of Urumqi River in the Tianshan Mountains and its implications, Chinese Science Bulletin, 1998, 43(20): 1749.

8. Shackleton, N. J., Opdyke, N. D., Oxygen-isotope and paleomagnetic stratigraphy of Pacific Core V.28-239, late Pliocene to latest Pleistocene, Memori- Geological Society of America, 145, Boulder, CO, United States, 1976, 449.

9. Abdrakhmatov, K. Y., Aldazhanoov, S. A., Hagert, B. H. et al., Relatively recent construction of the Tien Shan inferred from GPS measurements of present-day crustal deformation rates, Nature, 1996, 384: 450 .

10. Lu Huafu, Jia Dong, Chen Chuming et al., Natures and timing of the Kuqa Cenozoic structures, Earth Science Frontiers (in Chinese with English abstract), 1999, 6(4): 215.

11. Lu Huafu, Jia Chengzao, Jia Dong et al., Features of thrust wedge of deformation belt in the Kuqa rejuvenation foreland basin, Geo logical Journal of Chinese Universities (in Chinese with English abstract), 2001, 6(3): 258 .

12. Avouac, J. P., Tapponnier, P., Bai, M. et al., Active thrusting and folding along the northern Tien Shan and late Cenozoic rotation of the Tarim relative to Dzungaria and Kazakhstan, Journal of Geophysical Research, B, Solid Earth and Planets, 1993, 98(4): 6755.

13. Ying Shaofen, Huang Liren, Guo Liangqian et al., Horizontal deformation of Chinese continent obtained by GPS survey, Seismology and Geology (in Chinese with English abstract), 1999, 21(4): 459 .

(Received May 14, 2001; accepted September 17, 2001) 